\title{
Nitric oxide activity in childhood hypertension
}

\author{
C D A Goonasekera, V Shah, D D Rees, M J Dillon
}

\begin{abstract}
Objectives-To investigate nitric oxide (NO) activity in childhood hypertension using nitrite and nitrate (NOx) concentrations in plasma as an index of nitric oxide generation.

Design-Cross sectional study.

Setting-Tertiary care paediatric centre and district general hospitals in the UK.

Patients-Children attending the above centre for treatment of hypertension. The control subjects were normotensive healthy children attending district general hospitals for minor medical and surgical disorders.
\end{abstract}

Interventions-None.

Main outcome measures-Plasma (P) and urinary (U) NOx concentrations, blood pressure, and glomerular filtration rate.

Results-Sixteen normal children (mean age 6.9 years), 13 children with renovascular hypertension (mean age 7.8 years), and 25 children with hypertension associated with renal parenchymal disease (mean age 10.7 years) were studied. Mean (SD) $\mathbf{P}_{\mathrm{NOx}}$ values of children with hypertension with renovascular disease (15.3 (11.4) $\mu \mathrm{mol} / \mathrm{l})$ and renal parenchymal disease (18.3 (11.4) $\mu \mathrm{mol} / \mathrm{l})$ were significantly above that of normal children (11.9 (5.9) $\mu \mathrm{mol} / 1)$ after accounting for age and glomerular filtration rate influences. Higher concentrations of $P_{\mathrm{NO}}$ in normal children were associated with younger age, but not in the children with hypertension. Higher $\mathbf{P}_{\mathrm{NO}}$ concentrations were also associated with a lower glomerular filtration rate in normal children and children with hypertension with renal parenchymal disease, but not in the children with hypertension with renovascular disease. $U_{\text {NOx }}$ excretion expressed as a ratio against urine creatinine $\left(U_{\text {creat }}\right)$ excretion was not statistically different among the study groups.

Conclusions $-\mathbf{P}_{\mathrm{NOx}}$ is increased in children with hypertension even after statistical elimination of the glomerular filtration rate and age influences. This suggests a normal or increased NO synthase activity in childhood hypertension in contrast with adults with hypertension in whom it is described as reduced.

(Arch Dis Child 1997;77:11-16)

Keywords: childhood hypertension; nitric oxide; plasma nitrate; renal function
The overall incidence of hypertension in childhood is $1-3 \%{ }^{12}$ and it is associated with a significant morbidity and mortality, ${ }^{34}$ as in adults. ${ }^{56}$ The increased blood pressure in children is often secondary to some underlying cause, in contrast with that in adults in whom it is usually primary (essential). Over two thirds of such children develop hypertension due to an underlying acute or chronic renal disease or renovascular disease. ${ }^{3}$

Nitric oxide (NO), a molecule that has received extensive interest during recent years, is synthesised intracellularly from the amino acid L-arginine $e^{7-9}$ through the action of at least three isoforms of the enzyme nitric oxide synthase: endothelial (eNOS), inducible (iNOS), and neuronal (nNOS). The constitutive eNOS generates NO continuously and maintains the cardiovascular system in a state of constant active vasodilatation ${ }^{10}$ by activation of its receptor, the soluble guanylate cyclase, thereby increasing cyclic guanylate monophosphate and causing smooth muscle relaxation.

Many workers have shown that the basal NO dependent vasodilatation is decreased in human adults with essential hypertension. This may be due to the impaired generation of $\mathrm{NO}^{11-13}$ due to a genetic defect or acquired inhibition $^{14}$ of the NO synthase or reduced sensitivity of its receptor, soluble guanylate cyclase.

Experimental inhibition of eNOS by arginine analogues increases the peripheral arteriolar resistance ${ }^{15}$ and induces hypertension. ${ }^{16}{ }^{17} \mathrm{In}$ creased plasma concentrations of methylated arginine analogues have been reported in some forms of human hypertension, such as eclampsia, which may be of pathological significance in the associated hypertension. ${ }^{18-20}$ Genetically engineered eNOS 'knock out mice' with no detectable eNOS were also reported to be hypertensive. ${ }^{21}$ Therefore decreased NO generation or release may play a major part in the aetiology of various forms of hypertension. Nitric oxide has a short half life in biological systems and is rapidly metabolised to nitrite and nitrate, which are relatively slowly excreted in urine. These stable end products provide a useful marker of NO synthase activity in vivo.

We investigated plasma nitrite and nitrate concentrations (NOx) and urinary NOx excretion as an index of NO generation in a group of children and adolescents with hypertension.

\section{Patients and methods}

The study protocol was approved by the research and ethics committees of Great Ormond Street Hospital for Children NHS Trust and Institute of Child Health (GOS), Basildon and Thurrock, and North West 
Table 1 Plasma nitrate and nitrate (NOx), systolic blood pressure (SBP) and renal function in children with hypertension with renovascular disease, renal parenchymal diseases, and normal controls, along with details of each group

\begin{tabular}{llll}
\hline & $\begin{array}{l}\text { Normal subjects } \\
(n=16)\end{array}$ & $\begin{array}{l}\text { Renovascular } \\
\text { disease }(n=13)\end{array}$ & $\begin{array}{l}\text { Renal parenchymal } \\
\text { disease }(n=25)\end{array}$ \\
\hline Male:female ratio & $6: 10$ & $10: 3$ & $15: 10$ \\
Mean (SD) age (years) & $6.9(4.3)$ & $7.8(4.9)$ & $10.7(5.6)$ \\
GFR (ml/min/1.73m $\left.{ }^{2}\right)$ & $107.7(14.6)$ & $81.6(36.2)$ & $58.5(30.4)$ \\
Mean $(\mathrm{SD}) \mathrm{SBP}$ SD score & $-0.14(0.94)$ & $1.89(2.12)$ & $1.85(1.42)$ \\
Mean (SD) $\mathrm{P}_{\text {NOx }}(\mu \mathrm{mol} / \mathrm{l})$ & $11.9(5.9)$ & $15.3(11.4)$ & $18.3(11.4)$ \\
\hline
\end{tabular}

GFR=glomerular filtration rate.

Surrey health regions. Informed consent was obtained from the parents of all participating subjects.

All children with hypertension who attended GOS, a tertiary paediatric referral centre, were eligible for this study. Pyrexial patients with infections or other active systemic disorders were excluded. The children with hypertension were assessed by diagnostic criteria and investigative procedures routinely undertaken in our hospital, including several measurements of blood pressure, assessment of target organ damage, and investigations to elucidate the aetiology.

No dietary adjustments were made before the investigation. Blood samples were obtained in the morning. All patients had their systolic blood pressure, height, and weight measured on the day of investigation. Blood pressure was measured using a mercury sphygmomanometer, with Doppler ultrasound for the detection of systolic blood pressure in the very young (less than 5 years old) and a stethoscope (Korotkov phase 1) in older children, in line with the recommendations of the British Hypertension Society. ${ }^{22}$ These readings were standardised against 1987 task force data ${ }^{23}$ to eliminate age differences before comparison. Diastolic blood pressures were not measured. Plasma creatinine was measured using a standard enzymatic reaction (Kodak Ektachem).

Normotensive children were recruited from Frimley Park Hospital, Surrey and Basildon District General Hospital, Essex who attended for minor disorders such as behavioural problems, short stature, and for minor surgical procedures such as grommet insertion and hernia repair. Their blood pressures were also measured by the same observer (CG) before sampling. None had evidence of an active organic disease or infection at the time of sampling.

Venous blood was drawn into nitrite and nitrate free heparinised tubes on ice. The plasma was separated within four hours of collection and frozen at $-70^{\circ} \mathrm{C}$ until analysed. A duplicate whole blood sample was stored at room temperature for 24 hours before processing as just described to assess the stability of NOx in whole blood ex vivo.

Plasma nitrite concentrations were determined by first reducing the nitrate enzymatically using nitrate reductase from Aspergillus spp. ${ }^{24}$ Briefly, plasma samples were diluted $1: 4$ with Milli-Q distilled water and incubated with assay buffer (composition (mmol/l): $\mathrm{KH}_{2} \mathrm{PO}_{4}$, 50; NADPH, 0.6; FAD, 5.0; and nitrate reductase, $20 \mathrm{mU} ; \mathrm{pH} 7.5$ ) for one hour at $37^{\circ} \mathrm{C}$. A standard graph for nitrate was constructed by incubating sodium nitrate ( 1 , $100 \mu \mathrm{mol} / \mathrm{l}$ ) with the assay buffer. The resultant nitrite concentrations were determined by chemiluminesence and expressed as the amount of total plasma nitrite and nitrate (NOx) in $\mu \mathrm{mol} / 1$. The interassay variation was $14.1 \%$.

The glomerular filtration rate was calculated using the formula validated for children by Morris et $a l^{25}$ : glomerular filtration rate $(\mathrm{ml} /$ $\left.\min / 1.73 \mathrm{~m}^{2}\right)=(40 \times$ height $(\mathrm{cm})) /($ plasma creatinine $(\mu \mathrm{mol} / \mathrm{l}))$.

Wherever possible a urine sample was also collected from the subjects within four hours of the collection of the blood sample. Urinary NOx (chemiluminescence) and creatinine (Jaffé reaction) were measured and the urinary $\mathrm{NOx} /$ creatinine ratio was calculated to eliminate the confounding effects of urinary dilution and body weight before comparison. ${ }^{26}$

\section{STATISTICS}

The data were analysed using SPSS 6.0 (SPSS Inc) computer software. The systolic blood pressure was expressed as a SD score against the 1987 task force data ${ }^{23}$ using an inhouse computer program. The plasma NOx among all groups of children was compared using factorial analysis of variance (ANOVA) incorporating age and the glomerular filtration rate as covariates that may affect plasma NOx concentrations. The relations between plasma NOx $\left(\mathrm{P}_{\mathrm{NO}}\right)$ and renal function, systolic blood pressure SD score, and ages within the groups were assessed using Pearson's correlation coefficient.

Urine $\mathrm{NOx} /$ urine creatinine ratios $\left(\mathrm{U}_{\mathrm{NOx}} /\right.$ $\left.\mathrm{U}_{\text {creat }}\right)$ were $\log$ transformed for normalisation and compared among the groups using one way ANOVA. Correlations between $\mathrm{P}_{\mathrm{NOx}}$ and $\log \mathrm{U}_{\mathrm{NOx}} / \mathrm{U}_{\text {creat }}$ ratios within each group were also assessed.

\section{Results}

We studied 16 healthy normotensive children and 38 children with hypertension due to renovascular disease and renal parenchymal disease. Table 1 gives the descriptive data of each group. Thirty three of the 38 children with hypertension were receiving pharmacological treatment at the time of the blood sampling and none was receiving nitrovasodilator treatment. The remaining five were sampled before starting pharmacological treatment. The systolic blood pressure SD score of the groups with hypertension were significantly greater than those of normal controls (one way ANOVA, $F$ $=9.39, \mathrm{p}=0.0003)$.

PLASMA NOx $\left(\mathrm{P}_{\mathrm{NOx}}\right)$

The $\mathrm{P}_{\text {NOx }}$ of normal children decreased with age $(r=-0.67, \mathrm{p}=0.004$, fig 1A) and glomerular filtration rate $(r=-0.69, \mathrm{p}=0.003$, fig $1 \mathrm{~B})$. The $\mathrm{P}_{\mathrm{NOx}}$ of the subgroups of children with hypertension did not correlate with age (renovascular disease, $r=-0.3, \mathrm{p}=0.2$; renal parenchymal disease, $r=-0.06, \mathrm{p}=0.7)$. A lower glomerular filtration rate was associated with a higher $\mathrm{P}_{\mathrm{NOx}}$ in the children with hypertension 

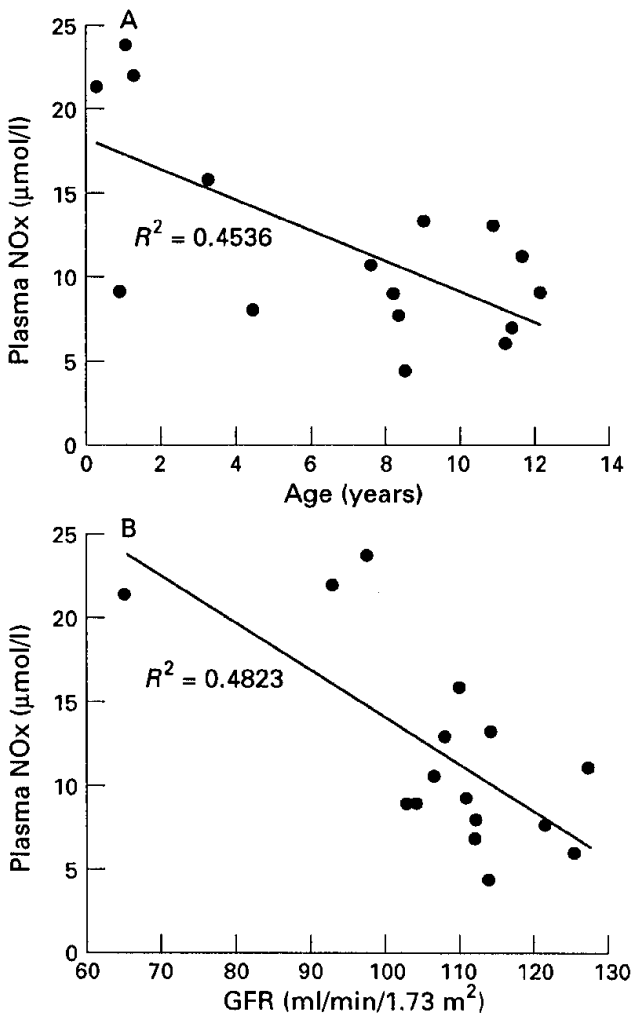

Figure 1 Scatter plots of plasma NOx $\left(P_{N O}\right)$ concentrations in normal children against $(A)$ age and $(B)$ glomerular filtration rate (GFR). The lowest glomerular filtration rate shown is that of an infant.

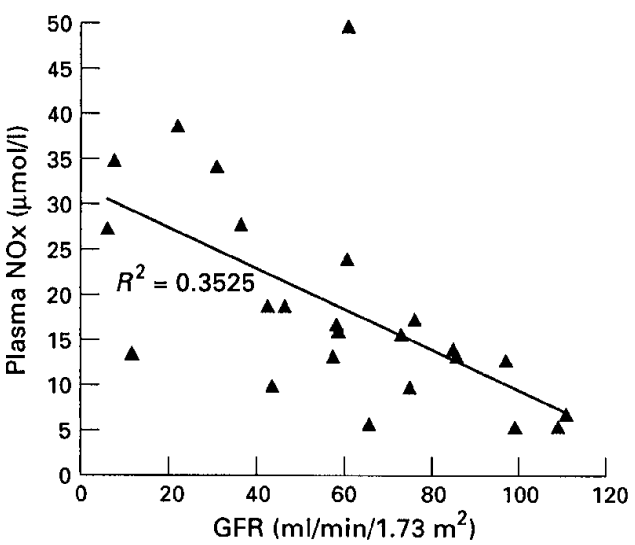

Figure 2 Plasma NOx $\left(P_{N o}\right)$ plotted against glomerular filtration rate (GFR) in children with hypertension with renal parenchymal disease.

with renal parenchymal disease $(r=0.59, \mathrm{p}=$ 0.002 , fig 2), but not in children with hypertension with renovascular disease $(r=$ $-0.04, \mathrm{p}=0.8$ )

After correction for the influences of age and glomerular filtration rate, $\mathrm{P}_{\mathrm{NOx}}$ remained significantly higher in the children with hypertension with renal parenchymal disease than in those with renovascular disease and the group of normal subjects (factorial ANOVA, explained $F=3.9$, p $=0.007$, fig 3$). \mathrm{P}_{\text {NOx }}$ did not, however, correlate with the systolic blood pressure SD score in any of the hypertensive groups (normal controls, $r=0.003, \mathrm{p}=0.9$; renovascular disease, $r=0.2, \mathrm{p}=0.4$; renal parenchymal disease, $r=0.1, \mathrm{p}=0.5$ ).

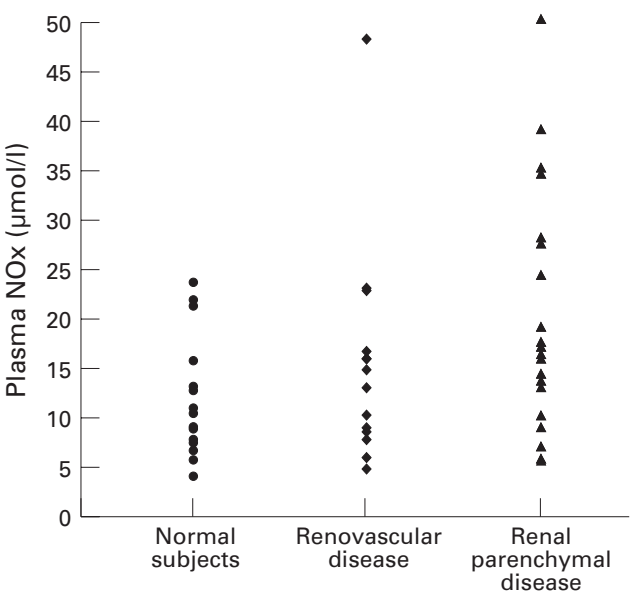

Figure 3 Plasma NOx $\left(P_{\text {No }}\right)$ concentrations in normal controls and in children with hypertension due to renovascular disease and renal parenchymal disease.

The highest concentration of $\mathrm{P}_{\mathrm{NOx}}$ (that is greater than $30 \mu \mathrm{mol} / \mathrm{l}$ ) was observed in five children with hypertension (fig 3), of whom three were sampled before pharmacological treatment started. Four of the five had hypertension due to renal parenchymal disease.

NOx IN WHOLE BLOOD EX VIVO

To assess the stability of NOx in whole blood at room temperature 28 duplicate samples of whole blood separated at four and 24 hours after collection were analysed. The mean (SD) $P_{\text {NOx }}$ of the samples at four hours was 15.62 (11.25) $\mu \mathrm{mol} / 1$. The $\mathrm{P}_{\mathrm{NOx}}$ concentration of the duplicate samples at 24 hours was 15.84 (11.03) $\mu \mathrm{mol} / \mathrm{l}$. Paired $t$ test analysis showed no significant difference (mean (SD) of difference 0.218 (3.096) $\mu \mathrm{mol} / 1,95 \%$ confidence interval -0.982 to $1.41, \mathrm{p}=0.71$ ).

URINE NOx

The descriptive data of urinary $\mathrm{NOx}\left(\mathrm{U}_{\mathrm{NOx}}\right)$ excretion and the correlation coefficients between $\mathrm{P}_{\mathrm{NOx}}$ and $\mathrm{U}_{\mathrm{NOx}} / \mathrm{U}_{\text {creat }}$ ratios are given in table 2; a significant correlation was only shown in the normal group (fig $4, \mathrm{n}=11$ as five subjects did not produce urine within four hours of blood sampling). Comparison of log transformed $\mathrm{U}_{\mathrm{NOx}} / \mathrm{U}_{\text {creat }}$ ratios showed a tendency for a low excretion of NOx in the hypertensive group with renal parenchymal disease, but did not reach statistical significance (one way ANOVA, $F=2.9, \mathrm{p}=0.06$, fig 5 ).

\section{Discussion}

The direct measurement of NO in vivo is difficult as it is rapidly inactivated in biological systems to the stable end products ${ }^{27}$ nitrite and nitrate. ${ }^{28}{ }^{29}$ Nitrite concentrations in plasma are low (about 5\%) compared with those of nitrate ${ }^{27}$ and eventually all NO metabolites are excreted as nitrates in urine ${ }^{30}$ without a diurnal variation. $^{27}$ Dietary nitrate contributes to plasma nitrate concentrations. Standardisation of diet is difficult in children, in particular in the very young, as their dietary patterns and requirements vary widely. For instance, infants 
Table 2 Median (range) values of urinary nitrate and nitrate $\left(U_{\text {Non }}\right)$, urinary creatinine $\left(U_{\text {crea }}\right)$ its ratios, and its correlation coefficient with $P_{N O x}$

\begin{tabular}{llll}
\hline & $\begin{array}{l}\text { Normal subjects } \\
(n=12)\end{array}$ & $\begin{array}{l}\text { Renovascular disease } \\
(n=13)\end{array}$ & $\begin{array}{l}\text { Renal parenchymal } \\
(n=18)\end{array}$ \\
\hline $\mathrm{U}_{\mathrm{NOx}}(\mathrm{mmol} / \mathrm{l})$ & $0.147(0.07-0.31)$ & $0.151(0.04-0.27)$ & $0.156(0.03-0.26)$ \\
$\mathrm{U}_{\text {creat }}(\mathrm{mmol} / \mathrm{l})$ & $6.95(0.5-54.0)$ & $2.60(1.3-7.6)$ & $5.30(1.7-13.9)$ \\
$\mathrm{U}_{\mathrm{NO}} / \mathrm{U}_{\text {creat }}$ ratio & $0.023(0.002-0.239)$ & $0.052(0.020-0.162)$ & $0.023(0.005-0.059)$ \\
$\begin{array}{l}\text { Correlation coefficient } \\
\text { between plasma Nox } \\
\text { and } \mathrm{U}_{\mathrm{NOx}} / \mathrm{U}_{\text {creat }} \text { ratio }\end{array}$ & $r=0.8 ; \mathrm{p}<0.001$ & $r=0.3 ; \mathrm{p}=0.4$ & $r=0.5 ; \mathrm{p}=0.1$ \\
\hline
\end{tabular}

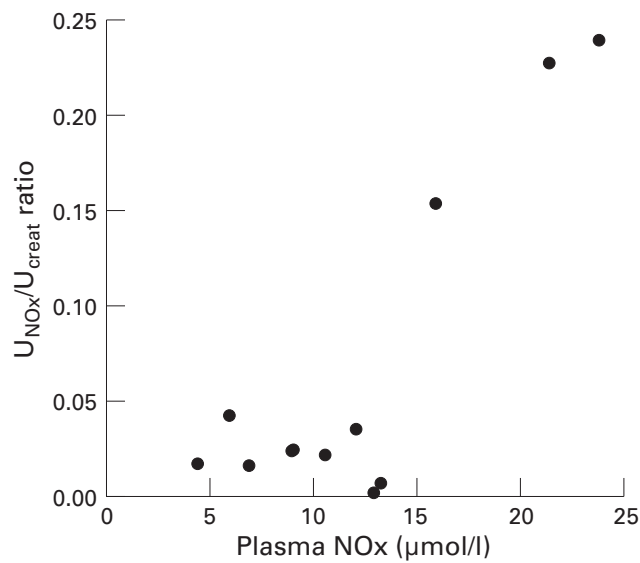

Figure 4 Scatter plot of plasma NOx $\left(P_{\text {NOU }}\right)$ concentration and concomitant urinary NOx/urinary creatinine ratio $\left(U_{N O x} / U_{\text {crea }}\right)$ in normal children.

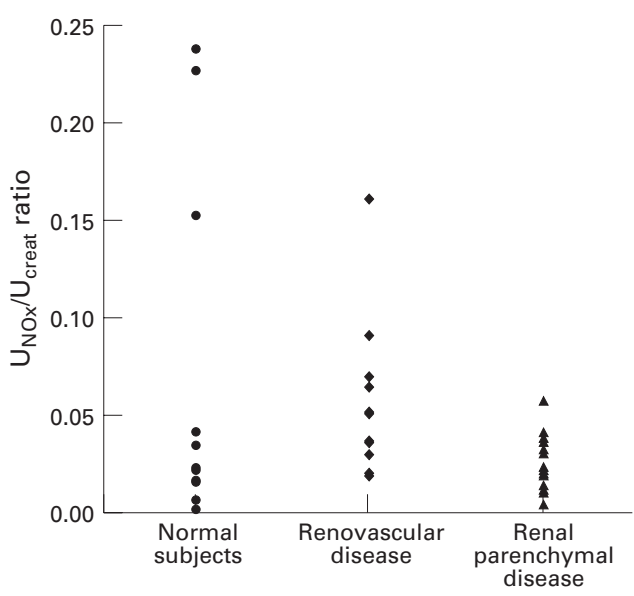

Figure 5 Urinary NOx $\left(U_{\text {No. }}\right)$ excretion expressed as a ratio against urine creatinine $\left(U_{\text {creap }}\right.$ ) excretion in normal control subjects and in children with hypertension due to renovascular disease and renal parenchymal disease.

would be mainly receiving a fluid and milk diet. Therefore we were unable to standardise dietary intake in this study. Mammals, however, produce nitrite and nitrate far in excess of that which can be accounted for by $\operatorname{diet}^{31}$ and the conversion of L-arginine to NO is the only known source of nitrite and nitrate production in mammalian tissues. ${ }^{32}$ Therefore $\mathrm{P}_{\mathrm{NOx}}$ may be used as an index of NO generation in vivo. ${ }^{33-35}$ It has been suggested that a lesser fraction of $\mathrm{NO}$ in whole blood is inactivated by the formation of methaemoglobin or nitrosylated haemoglobin, ${ }^{36}$ hence $\mathrm{P}_{\mathrm{NOx}}$ may change in samples of whole blood ex vivo. In this study no evidence was found for a change in $\mathrm{P}_{\mathrm{NOx}}$ in whole blood ex vivo for up to 24 hours at room temperature.
Nitrovasodilators used in the treatment of hypertension may alter plasma nitrate concentrations; however, none of the patients we studied were receiving this form of treatment. Nitric oxide formed through the action of an iNOS expressed in many cells (for example macrophages, smooth muscle) may also contribute to $\mathrm{P}_{\mathrm{NOx}}$ concentrations after activation due to infection and other inflammatory disorders. ${ }^{37-39}$ This error was minimised by including only apyrexial patients with no clinical evidence of an active systemic disorder. Low grade disease activity of the kidney itself may, however, have contributed to the increased plasma concentrations of NOx in some patients in this study, in particular in the group with renal parenchymal disease.

Only a limited number of untreated children with hypertension were available for this study as many were receiving antihypertensive treatment before arrival at this tertiary centre. NOx concentrations in three of the five untreated children with hypertension were greater than $30 \mu \mathrm{mol} / 1$, compared with only two of the 33 $(6 \%)$ in the treated group. These differences were not statistically comparable due to the heterogeneity of their aetiologies of hypertension, but were suggestive of a tendency for increased NO generation in the untreated group, either originating via increased constitutive eNOS activity from the vascular endothelial cells (a possible compensatory action against increased blood pressure) or through the expression of iNOS as a consequence of their pathological disorder leading to hypertension.

Most of the subjects recruited in this study were receiving more than one antihypertensive drug. We had no ethical permission to stop antihypertensive treatment before blood sampling as some of the patients had presented initially with severe life threatening complications such as encephalopathy and heart failure. Antihypertensive treatment may have altered the natural homoeostatic mechanisms that may involve NO pathways in hypertension and hence our results. The comparisons of blood pressure SD score among groups show significantly high mean scores in the hypertensive groups compared with those of controls, however (table 1). Therefore our findings are likely to be reflective of at least the homoeostatic trend of $\mathrm{NO}$ activity in high blood pressure.

The correlation between increased $\mathrm{P}_{\mathrm{NOx}}$ concentration with a lower glomerular filtration rate observed in normal children suggested that the low glomerular filtration rate in normal infants may contribute to their higher concentration of $\mathrm{P}_{\text {NOx }}$ in infancy. Thus the tendency for NOx concentrations in plasma to decrease with age in normal children may be a reflection of an age related increase in glomerular filtration rate.$^{40}$ This may be relevant, particularly within the first two years of life. On the other hand, this reduction in $\mathrm{P}_{\mathrm{NOx}}$ also coincides with the normal increase in blood pressure, again most marked within the first year of life. ${ }^{23}$ Therefore a reduction in eNOS activity with age may also partially explain the reduction of NOx with age and the age 
dependent increase in blood pressure in infancy. This is supported by the significant positive correlation found between $\mathrm{P}_{\mathrm{NOx}}$ and the $\mathrm{U}_{\text {NOx }} / \mathrm{U}_{\text {creat }}$ ratio in the normal group - that is, the higher the $\mathrm{P}_{\mathrm{NOx}}$, the higher the urinary excretion of nitrate. From this evidence it could be speculated that NO generation is possibly higher in infants, which may contribute to their lower blood pressure. Further studies are required in normotensive children to elucidate this clearly.

In this study we used $\mathrm{U}_{\mathrm{NO}} / \mathrm{U}_{\text {creat }}$ ratios instead of clearances to assess the urinary excretion of NOx. Although the use of renal clearances (calculated with steady state plasma and 24 hour urine excretion of NOx) would have been more appropriate in adults, the use in children of the urinary excretion of various substances in relation to the concentration of creatinine in urine has been a recognised reliable estimate of the excretion of a substance in children's urine for over 25 years. This methodology, based on the finding that creatinine excretion is relatively constant per kilogram of body weight in 24 hours, ${ }^{26}$ was initially validated for albumin excretion $^{41}$ and is now known to be valid for the assessment of the urinary excretion of a variety of other substances (tubular proteins, oxalate, calcium, magnesium, etc $)^{42}$ and is widely used. ${ }^{44-46}$ This use of $\mathrm{U}_{\mathrm{NOx}} / \mathrm{U}_{\text {creat }}$ ratios excludes the need for timed urine sampling in children (which is often inaccurate) and offers simplicity and greater reliability. ${ }^{42} 478$ In addition, it offers reliability for the estimation of substances that may not be stable in 24 hour urine collections. Therefore we believe that the use of $\mathrm{U}_{\mathrm{NOx}} / \mathrm{U}_{\text {creat }}$ ratios is a reliable and a simple method of comparison of urine NOx excretion among study groups.

We have shown that the reduced glomerular filtration rate (as a measure of renal function) is associated with an increase in the plasma concentration of $\mathrm{NOx}$ in children with hypertension associated with renal parenchymal disease. Although the lowest $\mathrm{U}_{\mathrm{NO} x} / \mathrm{U}_{\text {creat }}$ ratios were noted among the hypertensive group with renal parenchymal disease there was no direct correlation between the $\mathrm{P}_{\mathrm{NOx}}$ concentration and urinary NOx excretion within the hypertensive groups. This further supports the view that although high $\mathrm{P}_{\text {NOx }}$ correlates with a lower glomerular filtration rate in the patients with hypertension with renal parenchymal disease, an increased $\mathrm{P}_{\mathrm{NOx}}$ is not a direct consequence of a decreased excretion of NOx. Therefore the altered concentration of $\mathrm{P}_{\mathrm{NOx}}$ may reflect an increased production of NOx rather than a decreased urinary excretion, unless there is an alternative route of $\mathrm{NOx}$ elimination.

We were unable to show a correlation between the glomerular filtration rate and $\mathrm{P}_{\mathrm{NOx}}$ in the group with hypertension with renovascular disease, unlike in the group with renal parenchymal disease, although the two groups had lower than normal glomerular filtration rates. This may suggest that the renal function (glomerular filtration rate) is a less significant factor in influencing $\mathrm{P}_{\mathrm{NOx}}$ concentrations in certain groups of patients with hypertension. A similar observation has been made in patients with septic shock, a disorder with excessive NO generation, where $\mathrm{P}_{\mathrm{NOx}}$ seems to be less influenced by renal function. ${ }^{38}$ It is therefore possible that in the presence of abnormally increased NO production, $\mathrm{P}_{\mathrm{NOx}}$ is less influenced by renal function and may be excreted through alternative routes.

$\mathrm{P}_{\text {NOx }}$ did not correlate with the systolic blood pressure (expressed as SD scores) in any of the groups with hypertension. This may be due to the fact that slowly excreted NOx, the stable end product of NO metabolism, is more likely to reflect the cumulative levels of NO production during the preceding 24-48 hours. Unfortunately we did not have an assessment of the blood pressure profiles in our patients for the preceding 24-48 hours before the blood was taken for NOx estimation to test this hypothesis.

There was no evidence of a decreased $\mathrm{P}_{\mathrm{NOx}}$ activity in children and adolescents with hypertension. Indeed, $\mathrm{P}_{\mathrm{NOx}}$ appears to be either normal or increased. This suggests that NO generation in childhood hypertension is either normal or increased and a reduction in the eNOS activity is unlikely to affect the generation of hypertension in children. This theory is further supported by the complete reversibility of hypertension in some patients by the removal of the aetiology (for example renal artery stenosis). This difference in blood pressure-NO pathophysiology between children and adults may be related to the differences in the aetiology of hypertension; in adults it is predominantly essential in which there may be reduced vascular endothelial NO generation, whereas in children (in our study groups) the hypertension is predominantly secondary in which the endothelial generation of NO is normal or may even be increased. Animal studies have shown enhanced endothelial dependent NO release within the coronary resistance arteries of spontaneously hypertensive rats, which may represent a compensatory mechanism..$^{49}{ }^{50}$ A study by Habib et al has also shown evidence for an enhanced production of $\mathrm{NO}$ in the presence of high systemic vascular resistance in heart failure by showing the greatest increase in systemic vascular resistance in response to the NOS inhibitor L-NMMA in patients with the highest systemic vascular resistance. ${ }^{51}$ Therefore an increase in NO production is likely to occur, possibly as a counter-regulatory mechanism in the presence of increased vascular resistance. This could be the reason for the increased plasma concentrations of NOx detected in this study in some patients. It will be interesting to determine whether a similar situation may be applicable in adult subgroups of patients with hypertension.

NO generation appears to be increased or normal in childhood hypertension. This phenomenon suggests an upregulation of eNOS activity in some patients, either as a consequence of increased shear stress or hormonal influences on the vessel wall, or as a counter regulatory mechanism against hypertension. In addition, this may be a counter-regulatory phenomenon in childhood hypertension against increased levels of endogenous NOS inhibitor methylated arginine analogues due to 
the renal impairment which is often seen in these patients. The interpretation of plasma $\mathrm{NOx}$ concentrations as an index of NO generation individually, even after correcting for renal function and dietary influences, is unreliable as there appears to be another route of its elimination, especially in the presence of increased NO generation.

\section{Conclusions}

$\mathrm{P}_{\text {NOx }}$ is increased in children with hypertension. Although this may partly be explained by associated renal dysfunction, there is a logical argument to suggest normal or increased NO synthase activity in childhood hypertension, in contrast with adults with hypertension in whom it is described as reduced.

The authors thank Drs D Easton and P E Walker of Basildon and Frimley hospitals, respectively, and Dr S Roy and the staff of the renal unit at Great Ormond Street Hospital for Children for their assistance and Ms A M Wade for statistical advice. This work was supported by The John Herring and Friends Fund (Child Health Research Appeal Trust) and Kidney Research Aid Fund.

1 Leumann EP. Blood pressure and hypertension in childhood and adolescence. Ergeb Inn Med Kinderheilk 1979;43:10983.

2 Rames LK, Clarke WR, Conner WE, Reiter MA, Lauer RM. Normal blood pressures and the evaluation of sustained blood pressure elevation in children. The Muscatine Study. Pediatrics 1978;61:245-51.

3 Ingelfinger JR, Dillon MJ. Evaluation of secondary hyperIngelfinger J , Dillon M. Evaluation of secondary hyperPediatric nephrology. 3rd Ed. Baltimore: Williams and Pediatric nephrology. 3rd

4 Yetman RJ, Bonilla-Felix MA, Portman RJ. Primary hypertension in children and adolescents. In: Holliday MA, Barratt TM, Avner ED, eds. Pediatric nephrology. 3rd Ed. Baltimore: Williams and Wilkins, 1994:1117-45.

5 Sokolow M, Perloff DB. The prognosis of essential hypertension treated conservatively. Circulation 1961;23 697-713.

6 Kannel WB. Role of blood pressure in cardiovascular morbidity and mortality. Prog Cardiovasc Dis 1974;17:5-23.

7 Palmer RMJ, Ferrige AG, Moncada S. Nitric oxide release accounts for the biological activity of endothelium-derived relaxing factor. Nature 1987;327:524-6.

8 Furchgott RF. Studies on endothelium-dependent vasodilation and the endothelium-derived relaxing factor. Acto Physiol Scand 1990;139:257-70.

9 Ignarro LJ. Biosynthesis and metabolism of endotheliumIgnarro LJ. Biosynthesis and metabolism of endothelium-
derived nitric oxide. Annu Rev Pharmacol Toxicol 1990;30: derived $535-60$.

10 Moncada S. The L-arginine: nitric oxide pathway. Acto Physiol Scand 1992;145:201-27.

11 Calver A, Collier J, Moncada S, Vallance P. Effect of local intra-arterial NG-monomethyl-L-arginine in patients with hypertension: the nitric oxide dilator mechanism appears abnormal. f Hypertens 1992;10:1025-31.

12 Haynes WG, Noon JP, Walker BR, Webb DJ. Inhibition of nitric oxide synthesis increases blood pressure in healthy humans. F Hypertens 1993;11:1375-80.

13 Rees DD, Palmer RMJ, Moncada S. Role of endothelium derived nitric oxide in the regulation of blood pressure. Proc Natl Acad Sci USA 1989;86:3375-8.

14 Molnar M, Suto T, Toth T, Hertelendy F. Prolonged blockade of nitric oxide synthesis in gravid rats produces sustained hypertension, proteinuria, thrombocytopenia, and intrauterine growth retardation. Am $\mathcal{F}$ Obstet Gynecol 1994;170:1458-66.

15 Vallance P, Collier J, Moncada S. Effects of endotheliumderived nitric oxide on peripheral arterioler tone in man. ii: $997-1000$.

16 Baylis C, Mitruka B, Deng A. Chronic blockade of nitric oxide synthesis in the rat produces systemic hypertension and glomerular damage. F Clin Invest 1992;90:278-81.

17 Salazar FJ, Alberola A, Pinilla JM, Romero JC, Quesada T. Salt-induced increase in arterial pressure during nitric oxide synthesis inhibition. Hypertension 1993;22:49-55

18 Fickling SA, Williams D, Vallance P, Nussey SS, Whitley GS. Plasma concentrations of endogenous inhibitor of nitric oxide synthesis in normal pregnancy and preeclampsia. Lancet 1993;342:242-3.

19 Seligman SP, Buyon JP, Clancy RM, Young BK, Abramson SB. The role of nitric oxide in the pathogenesis of preeclampsia. Am f Obstet Gynecol 1994;171:944-8.

20 Yallampalli C, Garfield RE. Inhibition of nitric oxide synthesis in rats during pregnancy produces signs similar to
those of preeclampsia. Am $\mathcal{F}$ Obstet Gynecol 1993;169:131620.

21 Huang PL, Huang Z, Mashimo $\mathrm{H}$, et al. Hypertension in mice lacking the gene for endothelial nitric oxide synthase. Nature 1995;377:239-42.
22 O'Brien E, Petrie J, Littler W, et al. The British Hypertension Society protocol for the evaluation of blood pressure measuring devices. F Hypertens 1993;11:S43-62.

23 National Heart, Lung and Blood Institute, Bethesda, Maryland. Report of the second task force on blood pressure control in children. Pediatrics 1987;79:1-25.

24 Rees DD, Cunha FQ, Assreuy J, Herman AG, Moncada S. Sequential induction of nitric oxide synthase by Corynebacterium parvum in different organs of the mouse. $\mathrm{Br} F$ Pharmacol 1995;114:689-93.

25 Morris MC, Allanby CW, Toseland P, Haycock GB, Chantler C. Evaluation of a height/plasma creatinine formula in the measurement of glomerular filtration rate. Arch Dis Child 1982;57:611-5.

26 Graystone JE. Creatinine excretion during growth. In: Cheek DB, ed. Human growth. Philadelphia: Lea and Febiger, 1968:182-97.

27 Wennmalm A, Benthin G, Edlund A, et al. Metabolism and excretion of nitric oxide in humans. An experimental and clinical study. Circ Res 1993;73:1121-7.

28 Green LC, Wagner DA, Glogowski J, Skipper PL, Wishnok JS, Tannenbaum SR. Analysis of nitrate, nitrite, and [15N] nitrate in biological fluids. Anal Biochem 1982;126:131-8.

29 Wennmalm A, Benthin G, Petersson AS. Dependence of the metabolism of nitric oxide (NO) in healthy human whole blood on the oxygenation of its red cell haemoglobin. $\mathrm{Br} \mathrm{F}$ Pharmacol 1992;106:507-9.

30 Westfelt UN, Benthin G, Lundin S, Stenqvist O, Wennmalm A. Conversion of inhaled nitric oxide to nitrate in man. $\mathrm{Br}$ f Pharmacol 1995;114:1621-4.

31 Nathan C. Nitric oxide as a secretory product of mammalian cells. FASEB f 1992;6:3051-64.

32 Kilbourn RG, Gross SS, Jubran A, et al. NG-methyl-Larginine inhibits tumor necrosis factor-induced hypotension: implications for the involvement of nitric oxide. Proc Natl Acad Sci US A 1990;87:3629-32.

33 Bank N, Aynedjian HS. Role of EDRF (nitric oxide) in diabetic renal hyperfiltration. Kidney Int 1993;43:1306-12.

34 Ochoa JB, Curti B, Peitzman AB, et al. Increased circulating nitrogen oxides after human tumor immunotherapy. Correlation with toxic hemodynamic changes. 7 Natl Cancer Inst 1992;84:864-7.

35 Schultz PJ, Raij L. Endogenously synthesized nitric oxide prevents endotoxin-induced glomerular thrombosis. $f$ Clin Invest 1992;90:1718-25.

36 Tomoda A, Yubisui T, Tsuji A, Yoneyama Y. Kinetic studies on methemoglobin reduction by human red cell NADH cytochrome $b_{5}$ reductase. 7 Biol Chem 1979;254:3119-23.

37 Gomez Jimenez J, Salgado A, et al. L-arginine: nitric oxide pathway in endotoxemia and human septic shock. Crit Care Med 1995;23:253-8.

38 Wong HR, Carcillo JA, Burckart G, Shah N, Janosky JE. Increased serum nitrite and nitrate concentrations in children with the sepsis syndrome. Crit Care Med 1995;23: 835-42.

39 Sneddon JM, Ankier SI, Warrington SJ. Aspects of nitrate action and tolerance. In: Turner P, Volans GN, eds. Recent advances in clinical pharmacology and toxicology. New York: Churchill Livingstone, 1989:75-103.

40 Yared A, Ichikawa I. Renal blood flow and glomerular filtration rate. In: Holliday MA, Barratt TM, Avner ED, eds.
Pediatric nephrology. 3rd Ed. Baltimore: Williams and Pediatric nephrology.

41 Barratt TM, McLaine PN, Soothill JF. Albumin excretion as a measure of glomerular dysfunction in children. Arch Dis Child 1970;45:496-501.

42 Waller KV, Ward KM, Mahan JD, Wismatt DK. Current concepts in proteinuria. Clin Chem 1989;35:755-65.

43 Ghazali S, Barratt TM. Urinary excretion of calcium and magnesium in children. Arch Dis Child 1974;49:97-101.

44 Sherman RL, Drayer DE, Leyland-Jones BR, Reidenberg MM. N-acetyl-beta-glucosaminidase and beta ${ }_{2}^{-}$ microglobulin. Their urinary excretion in patients with renal parenchymal disease. Arch Intern Med 1983;143: 1183-5.

45 Tomlinson PA, Smellie JM, Prescod N, Dalton RN, Chantler C. Differential excretion of urinary proteins in children with vesicoureteric reflux and reflux nephropathy. Pediatr Nephrol 1994;8:21-5.

46 Jung $\mathrm{K}$. Urinary enzymes and low molecular weight proteins as markers of tubular dysfunction. Kidney Int 1994;46:S2933.

47 Houser M. Assessment of proteinuria using random urine samples. F Pediatr 1984;104:845-8.

48 Ginsberg JM, Chang BS, Matarese RA, Garella S. Use of single voided urine samples to estimate quantitative single voided urine samples to estimate
proteinuria. N Engl f Med 1983;309:1543-6.

49 Kelm M, Feelisch M, Krebber T, Deussen A, Motz W, Strauer BE. Role of nitric oxide in the regulation of coronary vascular tone in hearts from hypertensive rats. Maintenance of nitric oxide-forming capacity and increased basal production of nitric oxide. Hypertension 1995;25:186-93.

50 Kelm M, Feelisch M, Krebber T, Motz W, Strauer BE. The role of nitric oxide in the regulation of coronary vascular resistance in arterial hypertension: comparison of normotensive and spontaneously hypertensi

51 Pharmacol 1992;20(suppl 12):S183-6. Enhanced basal nitric oxide production in heart failure: another failed counter-regulatory vasodilator mechanism? Lancet 1994;344:371-3. 